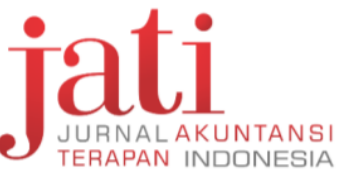

Jati: Jurnal Akuntansi Terapan Indonesia Vol 2 No 1 Hal 25-34 Maret 2019

DATA ARTIKEL:

Diterima: 8 Mei 2018

Direviu: 9 Juli 2018

Direvisi: 16 Juli 2018

Disetujui: 1 Agustus 2018

TOPIK ARTIKEL:

Akuntansi Keuangan, Good Corporate Governance

ABSTRAK: Tujuan penelitian ini adalah untuk menguji pengaruh risiko keuangan dan good corporate governance terhadap perataan laba pada perusahaan manufaktur di Indonesia. Good corporate governance diproksikan dengan dewan komisi independen, komite audit, kualitas audit, kepemilikan manajerial, dan kepemilikan institusional. Berdasarkan analisis regresi logistik dari 52 perusahaan yang melakukan perataan laba dan 84 perusahaan yang tidak melakukan perataan laba selama tahun 2010 hingga 2013, ditemukan bahwa ada pengaruh negatif yang signifikan antara risiko keuangan (RISK), kepemilikan manajerial (MOWN), dan kepemilikan institusional (INST) terhadap perataan laba di Indonesia. Temuan ini mengindikasikan bahwa semakin tinggi risiko keuangan, kepemilikan manajerial, dan kepemilikan institusional, maka semakin baik mekanisme monitoring dalam suatu perusahaan. Dengan demikian, akan mengurangi perataan laba yang dilakukan oleh manajemen.

Kata kunci: perataan laba, risiko keuangan, good corporate governance, kepemilikan manajerial, kepemilikan institusional

ABSTRACT: The objective of this research is to examine the effect of financial risk and good corporate governance towards income smoothing on manufacture companies in Indonesia. Good corporate governance is proxied by independent commission board, audit committee, audit quality, managerial ownership, and institutional ownership. According to the analysis of logistics regression of 52 companies that conduct income smoothing and 84

\section{Financial Risk, Good Corporate Governance dan Praktik Perataan Laba di Indonesia}

\author{
http://journal.umy.ac.id/index.php/jati \\ C) $2018 \mathrm{JATI}$. All rights reserved \\ DOI: 10.18196/jati.020114
}

\author{
MARFUAH*, WIDYA KRISNA MURTI \\ Universitas Islam Indonesia \\ *Email korespondensi: marfuah@uii.ac.id
}

companies that conduct non-income smoothing in 2010 to 2013, it is found that there is significant negative influence among financial risk (RISK), managerial ownership (MOWN), and institutional ownership (INST) variables towards income smoothing in Indonesia. This finding indicates that the higher financial risk, managerial ownership, and institutional ownership, the better monitoring mechanism in a company. Thus, it will decrease the income smoothing done by management.

Keywords: Income Smoothing, Financial Risk, Good Corporate Governance, Managerial Ownership, Institutional Ownership

\section{SITASI ARTIKEL:}

Mafuah \& Murti, W., K. (2019). Financial Risk, Good Corporate Governance dan Praktik Perataan Laba di Indonesia. Jati: Jurnal Akuntansi Terapan Indonesia, 2(1), 124-133.

\section{PENDAHULUAN}

Pada umumnya pemakai laporan keuangan terutama investor lebih menyukai perusahaan dengan laba besar dan stabil untuk menginvestasikan uangnya. Laba besar dan stabil akan menjadikan investor merasa aman karena kemungkinan fluktuasi laba yang kecil akan meningkatkan kemampuan investor untuk meramalkan laba perusahaan pada periode mendatang. Kondisi tersebut mendorong manajer untuk melaporkan laba yang stabil setiap tahunnya sehingga di mata investor nilai perusahaan akan dipandang semakin baik.

Salah satu tindakan manajemen agar kinerjanya dapat dinilai baik adalah dengan melakukan manajemen laba. Manajemen laba adalah pemilihan kebijakan akuntansi oleh manajemen yang berguna untuk mencapai beberapa tujuan tertentu. Salah satu bentuk earning management adalah perataan laba. Laba yang cenderung stabil atau tidak berfluktuasi dapat memperbaiki citra perusahaan di mata pi- 
hak eksternal karena laba yang stabil menggambarkan tingkat risiko perusahaan yang rendah. Praktik perataan laba dapat membuat informasi dalam laporan keuangan menjadi tidak andal sehingga pihak-pihak yang berkepentingan menjadi tidak mampu membuat keputusan bisnis yang tepat. Pentingnya keandalan informasi laporan keuangan melatarbelakangi penelitian ini (Utari et al. , 2017).

Penelitian tentang perataan laba telah banyak dilakukan sebelumnya, namun diperoleh hasil yang bervariasi. Noviana dan Yuyetta (2011) menemukan bahwa financial risk dan dividend payout ratio berpengaruh terhadap perataan laba, sedangkan profitability, firm value, managerial ownership dan public ownership tidak berpengaruh terhadap perataan laba. Aji dan Mita (2014) menemukan adanya pengaruh financial risk terhadap income smoothing, sedangkan Noviana (2011) menemukan bahwa perataan laba dipengaruhi oleh financial risk dan dividend payout ratio sedangkan profitabilitas, nilai perusahaan, dan kepemilikan publik tidak bepengaruh signifikan. Yulia (2013) menemukan bahwa profitabilitas, financial leverage, dan nilai saham memiliki pengaaruh yang signifikan terhadap perataan laba. Beberapa penelitian tersebut tidak konsisten dengan penelitian Prayudi dan Daud (2013) yang tidak berhasil membuktikan pengaruh financial risk terhadap perataan laba.

Purwanto (2009) dan Nurmalita (2011) yang meneliti pengaruh corporate governance yang terdiri dari dewan komisaris independen, komite audit dan reputasi auditor terhadap perataan laba tidak berhasil menemukan adanya pengaruh dewan komisaris independen, komite audit dan reputasi auditor terhadap perataan laba. Akan tetapi Marpaung dan Latrini (2014) yang meneliti mengenai pengaruh dewan komisaris independen, komite audit, kualitas audit dan kepemilikan manajerial terhadap perataan laba berhasil menemukan bahwa kualitas audit berpengaruh terhadap perataan laba, sedangkan, dewan komisaris independen, komite audit dan kepemilikan manajerial tidak berpengaruh terhadap perataan laba.

Mambraku dan Hadiprajitno (2014) menemukan adanya pengaruh antara kepemilikan manajemen dengan perataan laba Penelitian Rofika dan Zirman (2012) menyimpulkan bahwa kepemilikan manajerial, kepemilikan institusional dan komite audit tidak berpengaruh terhadap perataan laba. Demikian juga penelitian yang dilakukan oleh Widhianingrum (2012) dan Prabayanti dan Yasa (2011) yang tidak menemukan pengaruh kepemilikan institusional terhadap perataan laba. Oleh karena hasil penelitian tentang faktor yang mem- pengaruhi perataan laba masih belum menunjukkan hasil yang konsisten, maka penelitian ini dilakukan dengan tujuan untuk menguji pengaruh financial risk dan good corporate governance terhadap perataan laba pada perusahaan manufaktur di Indonesia.

\section{Financial Risk dan Perataan Laba}

Financial risk adalah tambahan risiko yang dibebankan kepada para pemegang saham biasa sebagai hasil dari keputusan untuk mendapatkan pendanaan melalui utang. Risiko ini terjadi karena para pemegang surat utang akan menerima pembayaran bunga secara tetap, sama sekali tidak menanggung risiko bisnis (Noviana dan Yuyetta, 2011). Financial leverage yang tinggi dapat menjadi pendorong manajer melakukan perataan laba. Tingginya financial leverage berarti bahwa semakin banyak sumber dana yang diperoleh perusahaan yang berasal dari utang. Bagaimanapun juga kreditur lebih menyukai laba yang tidak terlalu berfluktuasi. Selain itu, Semakin besar utang perusahaan maka semakin besar pula risiko yang dihadapi investor sehingga investor akan meminta tingkat keuntungan yang semakin tinggi. Akibat kondisi tersebut perusahaan cenderung untuk melakukan praktik perataan laba (Utari et al. , 2017). Oleh karena itu perusahaan yang memiliki rasio leverage tinggi akan mempunyai risiko yang tinggi pula sehingga laba perusahaan cendrung berfluktuasi. Berdasarkan uraian di atas hipotesis pertama dalam penelitian ini adalah:

H1: Financial Risk berpengaruh positif terhadap perataan laba

\section{Dewan Komisaris Independen dan Perataan Laba}

Dewan Komisaris Independen adalah sebuah badan dalam perusahaan yang biasanya beranggotakan dewan komisaris yang berasal dari luar perusahaan yang berfungsi untuk menilai kinerja perusahaan secara luas dan keseluruhan. Dewan Komisaris Independen juga diduga mempengaruhi praktik perataan laba. Ghader dan Mohsen (2014) juga menyatakan bahwa terdapat perbedaan jumlah board independence antara perusahaan yang melakukan perataan laba dengan perusahaan yang tidak melakukan perataan laba, yang mana perusahaan yang melakukan perataan laba memiliki jumlah board independence yang lebih sedikit dibandingkan dengan perusahaan yang tidak melakukan perataan laba. Komisaris independen berpengaruh negatif terhadap perataan laba, karena semakin banyak anggota komisaris independen dalam perusahaan maka proses pengawasan oleh komisaris independen akan semakin 
berkualitas sehingga dapat mencegah tindakan kecurangan terhadap laporan keuangan. Berdasarkan uraian di atas hipotesis kedua dalam penelitian ini adalah:

H2: Dewan Komisaris Independen berpengaruh negatif terhadap perataan laba.

\section{Komite Audit dan Perataan Laba}

Peran komite audit sangat diperlukan dalam melakukan pengawasan perusahaan. Noviawan dan Septiani (2013) menyatakan bahwa komite audit memiliki peran penting dan strategis dalam memelihara kredibilitas proses penyusunan laporan keuangan perusahaan seperti halnya menjaga berjalannya sistem pengawasan perusahaan yang memadai serta penerapan good corporate governance. Dengan adanya pengawasan dari komite audit, maka informasi yang disajikan dalam laporan keuangan lebih informatif dan berkualitas (Suryani dan Raharja, 2010).

Keberadaan komite audit di perusahaan diharapkan bisa meningkatkan pengawasan terhadap perusahaan sehingga tercipta perusahaan yang transparan guna menimalisir manajemen laba pada perusahaan (Anggraeni, 2013). Berdasarkan uraian di atas hipotesis ketiga dalam penelitian ini adalah:

H3: Komite Audit berpengaruh negatif terhadap perataan laba

\section{Kualitas Audit dan Perataan Laba}

Kualitas audit merupakan salah satu pertimbangan penting bagi investor untuk menilai kewajaran suatu laporan keuangan. Kualitas audit dipandang sebagai kemampuan untuk mempertinggi kualitas suatu laporan keuangan bagi perusahaan, maka auditor yang berkualitas tinggi diharapkan mampu meningkatkan kepercayaan investor (Praditia, 2010). Pemakai laporan keuangan lebih percaya pada laporan keuangan yang diaudit oleh auditor yang dianggap berkualitas dibandingkan dengan auditor yang kurang berkualitas, karena mereka menganggap bahwa untuk mempertahankan kredibilitasnya auditor akan lebih berhati-hati dalam melakukan proses audit untuk mendeteksi salah saji atau kecurangan. Berdasarkan uraian di atas hipotesis ketiga dalam penelitian ini adalah:

H4: Kualitas Audit berpengaruh negatif terhadap perataan laba

\section{Kepemilikan Manajerial dan Perataan Laba}

Manajer yang memiliki saham dalam perusahaan akan berusaha meningkatkan kinerja perusahaan. Semakin meningkat proporsi kepemilikan manajerial maka semakin baik kinerja perusahaan, karena manajer akan memiliki kepentingan yang sejajar dengan pemilik sehingga akan mengurangi konflik keagenan. Jika konflik keagenan dapat dikurangi, manajer termotivasi untuk meningkatkan kinerja perusahaan (Amanza, 2012).

Manajer yang sekaligus juga pemegang saham akan menghindari pelaporan keuangan yang menyesatkan, karena dalam hal ini manajer berperan sebagai investor dan pengawas dalam perusahaan yang menginginkan laporan keuangan bersifat relevan dan dapat dipertanggungjawabkan. Mambraku dan Hadiprajitno (2014) menemukan adanya pengaruh negatif antara kepemilikan manajemen dengan income smoothing. Semakin tinggi kepemilikan saham oleh manajemen maka perataan laba akan semkin menurun. Berdasarkan uraian di atas hipotesis keempat dalam penelitian ini adalah:

H5: Kepemilikan Manajerial berpengaruh nega-tif terhadap perataan laba

\section{Kepemilikan Institusional dan Perataan Laba}

Kepemilikan saham oleh investor institusional berperan untuk memonitor kinerja manajemen perusahaan dengan lebih efektif dan mempengaruhi manajer dalam pengambilan keputusan agar manajemen perusahaan tidak bertindak sesuai keinginannya sendiri (Praditia, 2010). Kepemilikan institusional dapat memantau secara tepat dan profesional terhadap perkembangan investasi yang ada pada perusahaan. Dengan adanya tingkat pengawasan yang tinggi oleh investor institusional terhadap manajemen maka potensi kecurangan yang dilakukan manajemen dapat ditekan.

Mitani (2010) menemukan adanya pengaruh negatif atara kepemilikan institusional terhadap manajemen laba. Artinya, semakin besar kepemilikan saham oleh investor institusional maka semakin kecil manajemen laba. Berdasarkan uraian di atas hipotesis keempat dalam penelitian ini adalah:

H6: Kepemilikan Institusional berpengaruh negatif terhadap perataan laba

\section{Kerangka Pemikiran Teoritis \\ Kerangka pemikiran teoritis disajikan pada Gambar 1 berikut.}


VARIABEL INDEPENDEN

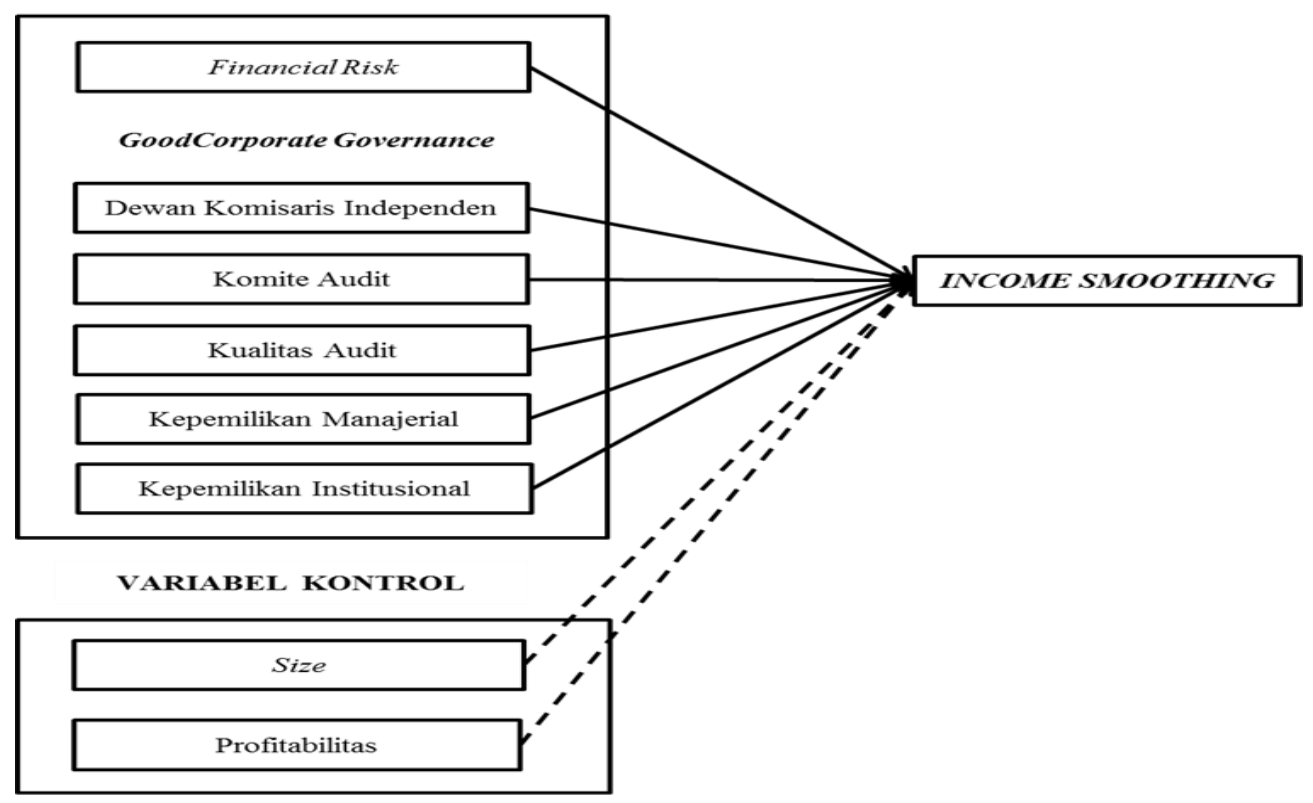

Gambar 1. Kerangka Pemikiran Teoritis

Tabel 1. Proses Pemilihan Sampel Penelitian

\begin{tabular}{|c|c|}
\hline Kriteria & Jumlah \\
\hline Perusahan manufaktur yang terdaftar di BEI pada tahun 2013-2016 & 139 \\
\hline Perusahaan mengalami delisting pada periode pengamatan & (3) \\
\hline Perusahaan melakukan akuisisi ataupun merger & (0) \\
\hline Perusahaan tidak mengeluarkan annual report & (16) \\
\hline Perusahaan mengalami rugi selama periode pengamatan & (13) \\
\hline $\begin{array}{l}\text { Perusahaan tidak menggunakan satuan mata uang rupiah dalam laporan } \\
\text { keuangannya. }\end{array}$ & (8) \\
\hline Perusahaan tidak memiliki data lengkap yang dibutuhkan dalam penelitian & $(65)$ \\
\hline Jumlah sampel per tahun & 34 \\
\hline Total sampel selama 4 tahun & 136 \\
\hline
\end{tabular}

Populasi yang digunakan dalam penelitian ini adalah semua perusahaan manufaktur yang terdaftar di Bursa Efek Indonesia tahun 2013-2016. Berdasarkan metode purposive sampling diperoleh sampel penelitian sebanyak 34 perusahaan per tahun sehingga total keseluruhan sampel sebanyak 136 perusahaan. Kemudian total sampel 136 dikelompokkan menjadi 2 subsampel, yaitu subsampel perata laba apabila CV Sales > CV Earning sebanyak 52 dan subsample non perata laba apabila CV Sales < CV Earning sebanyak 84.

Proses pemilihan sampel penelitian disajikan pada tabel 01 berikut ini

\section{Variabel Penelitian}

Variabel yang digunakan dalam penelitian ini terdiri dari variabel dependen, variabel independen dan variabel kontrol. Nama variabel

\section{Metode Analisis Data}

Metode analisis data untuk menguji hipotesis dalam penelitian ini menggunakan regresi logistik dengan persamaan berikut:

IS $=\alpha+\beta_{1}$. RISK $+\beta_{2}$. INDCOMIS $+\beta_{3}$. AUDCOM $+\beta_{4}$ . AUDQUALITY $+\beta_{5}$. MOWN $+\beta_{6}$. INST $+\beta_{7}$. SIZE $+\beta_{8}$. PROF $+€$

Keterangan :

$\begin{array}{ll}a & =\text { Konstanta } \\ \beta & =\text { Koefisien Regresi Logit } \\ \text { IS } & \text { Income smoothing } \\ \text { FINRISK = Financial } & \text { Risk } \\ \begin{array}{ll}\text { INDCOMIS } & =\text { Dewan Komisaris Independen } \\ \text { AUDCOM } & =\text { Komite Audit } \\ \text { AUDQUALITY= Kualitas Audit } & \\ \text { MOWN = Kepemilikan Manajerial } & \\ \text { INST } & =\text { Kepemilikan Institusional }\end{array}\end{array}$


PROFIT $=$ Profitabilitas

$\begin{array}{cl}\text { Keterangan } & \text { Nama Variabel } \\ \text { Variabel } & \text { Income } \\ \text { Dependen } & \text { smoothing (IS) }\end{array}$

Variabel Financial Risk Independen (RISK)

Good

Corporate

Governance

\begin{abstract}
Variabel
\end{abstract}
Ukuran

kontrol

Perusahaan

(SIZE)

Profitabilitas

(PROF)

\section{HASIL DAN PEMBAHASAN}

\section{Deskripsi Data}

Sebelum dilakukan pengujian hipotesis, terlebih dahulu disajikan deskripsi data variabel dengan rumus:

INDCOMIS :

AUDCOM:
Tabel 2. Variabel Independen dan Pengukurannya

Pengukuran Variabel

Variabel Income smoothing (IS) dilakukan dengan menghitung Index eckel

Index eckel $=\underline{\text { CV Sales }}$

$$
\text { CV Earning }
$$

Selanjutnya perusahaan dikelompokkan sebagai perata laba apabila CV Sales > CV Earning dan diberi skor 1, sebaliknya dikelompokkan perusahaan bukan perata apabila CV Sales < CV Earning dan diberi skor 0.

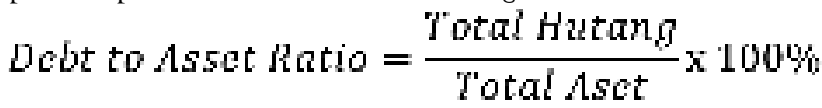

Wumlah anggota dewan komisaris dori luar perusahaon

$$
\text { Seluruh anggota dewan komisaris porusahoan }
$$

Komite Audit $=$ EKomite audit dalam perusahaon

AUDQUALITY: Kualitas Audit diukur dengan variabel dummy. Skor 1, apabila laporan keuangan perusahaan diaudit oleh Kantor Akuntan Publik yang tergabung dalam The Big Four dan skor 0 untuk sebaliknya.

MOWN: Proporsi saham oleh manajemen

INST: Proporsi saham oleh investor institusi

$S I Z E$ = Ln 'Total Aset

$$
R O A=\frac{\text { Laba Bersih setelah Pajak }}{\text { Total Aset }} \times 100 \%
$$

penelitian yang meliputi nilai minimum, maksimun, mean dan standar deviasi pada tabel 03. Panel A menyajikan deskripsi data untuk total sampel, Panel $B$ untuk sub sampel perata laba dan Panel $C$ untuk sub sampel non perata laba.

Tabel 3. Statistik Deskriptif Variabel Penelitian

Panel A: Total Sampel

\begin{tabular}{|l|r|r|r|r|r|}
\hline & \multicolumn{1}{|c|}{$\mathrm{N}$} & \multicolumn{1}{c|}{ Minimum } & \multicolumn{1}{c|}{ Maximum } & \multicolumn{1}{c|}{ Mean } & Std. Deviation \\
\hline IS & 136 & 0 & 1 &, 38 &, 488 \\
RISK & 136 &, 037232 & 1,107059 &, 44377490 &, 196743442 \\
INDCOMIS & 136 &, 250000 &, 750000 &, 38302199 &, 092539788 \\
& & & & & \\
AUDCOM & 136 & 3 & 4 & 3,06 &, 236 \\
AUDQUALITY & 136 & 0 & 1 &, 26 &, 443 \\
MOWN & 136 &, 000000 &, 256198 &, 06089011 &, 079482171 \\
INST & 136 &, 225131 &, 979845 &, 67313581 &, 184282945 \\
SIZE & 136 & 25,082536 & 31,988919 & 27,59410540 & 1,526133658 \\
PROF & 136 &,, 091921 &, 669590 &, 07546101 &, 080525181 \\
& & & & & \\
\hline
\end{tabular}


Panel B: Subsampel Perata Laba

\begin{tabular}{|l|r|r|r|r|r|}
\hline & $\mathrm{N}$ & \multicolumn{1}{|c|}{ Minimum } & Maximum & \multicolumn{1}{c|}{ Mean } & $\begin{array}{c}\text { Std. } \\
\text { Deviation }\end{array}$ \\
\hline IS & 52 & 1 & 1 & 1,00 &, 000 \\
RISK & 52 &, 128503 &, 728138 &, 39090512 &, 176094786 \\
INDCOMIS & 52 &, 250000 &, 750000 &, 37990946 &, 112349072 \\
AUDCOM & 52 & 3 & 4 & 3,06 &, 235 \\
AUDQUALITY & 52 & 0 & 1 &, 29 &, 457 \\
MOWN & 52 &, 000000 &, 256198 &, 04201292 &, 059729007 \\
INST & 52 &, 322156 &, 960912 &, 65077708 &, 158728803 \\
SIZE & 52 & 25,176941 & 31,988919 & 27,73567981 & 1,98124925 \\
& & & & & 3 \\
PROF & 52 &,- 038542 &, 321145 &, 08823969 &, 066561001 \\
& & & & & \\
\hline
\end{tabular}

Panel C: Subsampel Non Perata Laba

\begin{tabular}{|l|r|r|r|r|r|}
\hline & $\mathrm{N}$ & Minimum & Maximum & Mean & $\begin{array}{c}\text { Std. } \\
\text { Deviation }\end{array}$ \\
\hline IS & 84 & 0 & 0 &, 00 &, 000 \\
RISK & 84 &, 037232 & 1,107059 &, 47650381 &, 202656131 \\
INDCOMIS & 84 &, 250000 &, 500000 &, 38494880 &, 078505164 \\
AUDCOM & 84 & 3 & 4 & 3,06 &, 238 \\
AUDQUALITY & 84 & 0 & 1 &, 25 &, 436 \\
MOWN & 84 &, 000000 &, 256198 &, 07257599 &, 087873451 \\
INST & 84 &, 225131 &, 979845 &, 68697693 &, 198111662 \\
SIZE & 84 & 25,082536 & 31,487023 & 27,50646410 & 1,164464288 \\
PROF & 84 &,- 091921 &, 669590 &, 06755039 &, 087514857 \\
& & & & & \\
\hline
\end{tabular}

Sumber: Hasil Olah Data, 2015.

\section{Analisis Regresi Logistik}

Hasil uji hipotesis penelitian dengan model

regresi logistik disajikan pada tabel 04 berikut.

\section{Persamaan Regresi:}

IS $=\quad 4,287-4,592$ RISK - 1,221INDCOMIS -

1,169AUDCOM + 0,863AUDQUALITY - 15,088MOWN

- 4,927INST + 0,164SIZE + 3,334PROF

Tabel 04

Hasil Uji Regresi Logistik

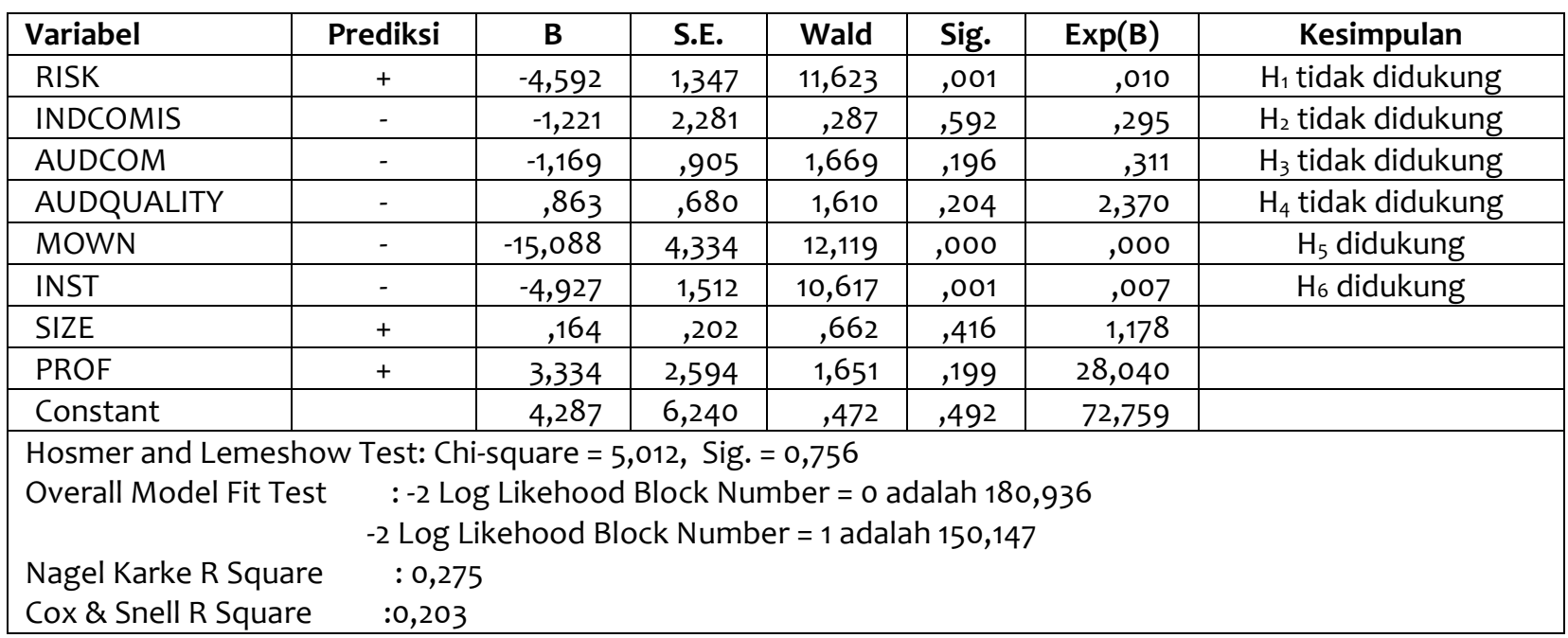

Sumber: Hasil Olah Data, 2015. 
Langkah pertama yang dilakukan pada analisis regresi logistic adalah menilai kelayakan model regresi. Berdasarkan hasil uji Hosmer and Lemeshow diperoleh nilai Chi-square sebesar 5,012 dengan sig 0,756. Hal ini menunjukkan bahwa model mampu memprediksi nilai observasi karena cocok dengan data observasinya.

Langkah kedua adalah menilai keseluruhan model regresi dengan membandingkan nilai -2 Log Likelihood Block Number $=0$ dan -2 Log Likelihood Block Number $=1$. Adanya penurunan yang signifikan nilai -2 Log Likelihood Block Number $=0$ sebesar 180,936 menjadi 150,147 pada model -2 Log Likelihood Block Number = 1, menunjukkan bahwa model regresi dengan memasukkan semua variabel independen lebih baik atau dengan kata lain model yang dihipotesiskan fit dengan data. Langkah selanjutnya adalah menguji pengaruh dari masingmasing variabel independen terhadap variabel dependennya.

\section{Pengaruh Financial Risk terhadap Perataan Laba}

Koefisien variable RISK adalah $-4,592$ dengan nilai signifikansi sebesar 0,001 menunjukkan bahwa financial risk berpengaruh negatif signifikan terhadap perataan laba. Hasil ini berlawanan dengan hipotesis pertama yang menyatakan bahwa financial risk berpengaruh positif terhadap perataan laba, sehingga Ha1 tidak berhasil didukung. Hasil penelitian ini mengindikasikan bahwa semakin tinggi financial risk justru akan mengurangi kecenderungan perusahaan untuk melakukan perataan laba ataupun sebaliknya. Hasil ini juga didukung dari nilai mean variabel fianancial risks pada subsampel perata laba lebih rendah dibanding financial risk pada subsampel non perata laba masing-masing sebesar 0,39090512 untuk financial risk subsampel perata laba dan 0,47650381 financial risk subsample non perata laba .

Adanya hasil yang bertentangan dengan hipotesis pertama kemungkinan disebabkan dengan adanya kebijakan hutang yang tinggi maka pihak ketiga akan selalu mengawasi aktivitas perusahaan. Semakin besar hutang yang dimiliki perusahaan maka pengawasan yang dilakukan oleh pihak ketiga terhadap perusahaan juga semakin ketat sehingga akan menurunkan kecenderungan pihak manajemen perusahaan untuk melakukan perataan laba.

Hasil penelitian ini tidak sejalan dengan penelitian yang dilakukan oleh Aji dan Mita (2010) yang menemukan bahwa risiko keuangan berpengaruh positif terhadap perataan laba. Akan tetapi hasil penelitian ini sesuai dengan penelitian
Wijaya (2009) yang menemukan bahwa financial risk berpengaruh negatif terhadap perataan laba.

\section{Pengaruh Dewan Komisaris Independen terhadap Perataan Laba}

Besarnya koefisien variabel INDCOMIS adalah -1,221 dengan nilai signifikansi sebesar 0,592 menunjukkan bahwa hipotesis kedua penelitian yang menyatakan bahwa dewan komisaris independen berpengaruh negatif terhadap perataan laba tidak berhasil didukung.Tidak didukungnya hipotesis kedua ini kemungkinan disebabkan karena proporsi dewan komisaris independen pada perusahaan sampel masih rendah yaitu sebesar 0,38 sehingga keberadaanya belum mampu menjalankan fungsi monitoring atas laporan keuangan dengan efektif. Oleh karena itu keberadaan dewan komisaris independen belum mampu mengurangi perataan laba. Hasil penelitian ini sesuai dengan penelitian yang dilakukan oleh Tampubolon (2012) dan Marpaung dan Latrini (2014) yang juga tidak berhasil membuktikan pengaruh dewan komisaris independen terhadap perataan laba.

\section{Pengaruh Komite Audit terhadap Perataan Laba}

Besarnya koefisien variabel AUDCOM adalah -1,169 dengan signifikansi sebesar 0,196 menunjukkan bahwa hipotesis ketiga yang menyatakan bahwa komite audit berpengaruh negatif terhadap perataan laba tidak berhasil didukung. Hasil penelitian ini mengindikasikan bahwa keberadaan komite audit dalam perusahaan sampel belum mampu membatasi terjadinya perataan laba. Hasil ini didukung dari nilai mean variabel komite audit yang nilainya sama baik pada sampel keseluruhan, subsampel perata laba maupun subsampel non perta laba, yaitu sebesar 3,06 .

Hasil ini tidak sesuai dengan penelitian Tampubolon (2012) yang berhasil membuktikan bahwa komite audit berpengaruh terhadap perataan laba, akan tetapi sejalan dengan penelitian Rofika dan Zirman (2012) serta Nurmalita (2011) yang tidak menemukan bahwa komite audit berpengaruh terhadap perataan laba.

Hasil penelitian yang menunjukkan tidak adanya pengaruh komite audit terhadap perataan laba ini kemungkinan disebabkan karena pembentukan komite audit hanya sebagai pemenuhan ketentuan BEI nomor: KEP-399/BEJ/072001 tentang Peraturan Pencatatan Efek di Bursa poin $C$ bahwa keanggotaan komite audit sekurangkurangnya terdiri dari tiga orang anggota. Keberadaan komite audit dalam perusahaan belum 
mampu melakukan fungsi monitoring terhadap kinerja manajemen sehingga belum mampu membatasi perataan laba.

\section{Pengaruh Kualitas Audit terhadap Perataan Laba} Besarnya koefisien variabel AUDQUALITY adalah 0,863 dengan signifikansi sebesar 0,204 menunjukkan bahwa hipotesis keempat yang menyatakan bahwa kualitas audit berpengaruh negatif terhadap perataan laba tidak berhasil didukung. Hasil penelitian ini mengindikasikan bahwa kualitas audit yang diproksikan dengan audit yang dilakukan oleh KAP the Big 4 tidak mampu membatasi terjadinya perataan laba. Tidak didukungnya pengaruh kualitas audit terhadap perataan laba pada penelitian ini kemungkinan disebabkan penggunaan KAP the Big 4 sebagai proksi kualitas audit kurang tepat.

Hasil penelitian ini tidak sejalan dengan penelitian yang dilakukan oleh Marpaung dan Latrini (2014) yang menemukan bahwa kualitas audit berpengaruh terhadap perataan laba. Akan tetapi penelitian ini sesuai dengan penelitian yang dilakukan oleh Sulistyawati (2013) serta Gayatri dan Wirakusuma (2013) yang juga tidak berhasil membuktikan bahwa kualitas audit berpengaruh terhadap perataan laba.

\section{Pengaruh Kepemilikan Manajerial terhadap Perataan Laba}

Besarnya koefisien variabel MOWN adalah 15,088 dengan nilai signifikansi sebesar 0,000 menunjukkan bahwa kepemilikan manajerial berpengaruh negatif terhadap perataan laba. Oleh karena itu hipotesis kelima yang menyatakan bahwa kepemilikan manajerial berpengaruh negatif terhadap perataan laba berhasil didukung. Hasil penelitian ini konsisten dengan temuan Mambraku dan Hadiprajitno (2014) yang menyimpulkan adanya pengaruh antara kepemilikan manajerial dengan income smoothing.

Hasil penelitian ini mengindikasikan bahwa semakin besar kepemilikan saham oleh manajemen akan mengurangi kecenderungan manajemen untuk melakukan perataan laba. Kepemilikan saham yang besar oleh pihak manajemen mengakibatkan manajemen lebih berhati-hati dalam mengambil suatu keputusan karena manajemen akan ikut merasakan akibat secara langsung atas keputusan yang diambil.

\section{Pengaruh Kepemilikan Institusional terhadap} Perataan Laba

Besarnya koefisien variabel INST adalah 4,927 dengan nilai signifikansi sebesar 0,001 menunjukkan bahwa hipotesis keenam yang menyatakan bahwa kepemilikan institusional berpengaruh negatif terhadap perataan laba berhasil didukung. Hasil penelitian ini konsisten dengan penelitian Mitani (2010) yang menemukan adanya pengaruh negative kepemilikan institusional terhadap manajemen laba.

Kepemilikan saham oleh pihak institusional merupakan salah satu mekanisme untuk mengawasi kinerja manajemen. Pemegang saham institusional dapat mengimbangi informasi yang dimiliki oleh manajemen sehingga asimetri informasi yang terjadi antara manajemen dan pemilik menjadi rendah. Kepemilikan saham oleh investor institusional juga berperan untuk memonitor kinerja manajemen perusahaan dengan lebih efektif dan mempengaruhi manajer dalam pengambilan keputusan agar manajemen perusahaan tidak bertindak sesuai keinginannya sendiri sehingga potensi kecurangan dapat dikurangi.

Berdasarkan perolehan data, peneliti akan memasukkan data-data tersebut ke dalam model logika yang tercantum pada gambar 2. Selanjutnya, peneliti akan mengurutkan data yang disusun dengan model logika secara urut dari kiri ke kanan, dimulai dari sumber daya hingga dampak.

\section{SIMPULAN}

Penelitian ini bertujuan untuk menganalisis pengaruh financial risk dan corporate governance terhadap perataan laba. Corporate governance diproksikan dengan dewan komisaris independen, komite audit, kualitas audit, kepemilikan manajerial dan kepemilikan institusional. Berdasarkan hasil analisis logistic regression disimpulkan sebagai berikut:

1. Hipotesis pertama yang menyatakan bahwa financial risk berpengaruh positip terhadap perataan laba tidak berhasil didukung, karena financial risk justru berpengaruh negatif signifikan terhadap perataan laba. Hasil ini kemungkinan disebabkan karena dengan adanya kebijakan hutang yang tinggi, maka perusahaan tersebut akan justru mendapat pengawasan yang ketat dari pihak eksternal sehingga akan membatasi perilaku manajemen untuk melakukan perataan laba.

2. Hipotesis 5 dan hipotesis 6 berhasil didukung, artinya variabel kepemilikan manajerial dan kepemilikan institusional berpengaruh negatif signifikan terhadap perataan laba. Hal ini menunjukkan bahwa semakin besar kepemilikan saham oleh pihak manajemen dan investor institusional akan mengurangi kecenderungan manajemen dalam melakukan perataan laba. 
3. Hipotesis 2, hipotesis 3 dan hipotesis 4 tidak berhasil didukung, artinya keberadaan dewan komisaris independen dan komite audit dalam perusahaan belum mampu melakukan monitoring secara efektif sehingga belum mampu mengurangi perataan laba pada perusahaan. Demikian juga kualitas audit yang diproksikan dengan KAP the Big Four belum mampu mengurangi terjadinya perataan laba.

Hasil penelitian ini memberikan kontribusi bagi investor dan kreditor dalam menilai kualitas laba yang dilaporkan oleh perusahaan untuk pengambilan keputusan. Perusahaan dengan financial risk yang tinggi, kepemilikan manajerial dan kepemilikan institusional yang besar cenderung mempunyai kualitas laba yang lebih baik, karena pada perusahaan tersebut tidak ditemukan terjadinya perataan laba. Hal ini disebabkan karena pada perusahaan dengan financial risk yang tinggi cenderung akan diawasi oleh pihak ketiga. Demikian juga dengan kepemilikan saham oleh manajemen dan oleh institusional yang besar akan membatasi perilaku oportunistik manajemen sehingga perataan laba dapat dikurangi.

Tidak didukungnya hipotesis tentang pengaruh negatif komite audit dan kualitas audit terhadap perataan laba, kemungkinan disebabkan pemilihan proksi variabel yang kurang tepat. Diharapkan penelitian yang akan datang bisa mengganti proksi variabel komite audit dengan proporsi komite audit independen dan variabel kualitas audit dengan audit tenure atau auditor spesialis industri.

\section{DAFTAR PUSTAKA}

Aji, D. Y., dan Aria, F, M. (2010). Pengaruh Profitabilitas, Risiko Keuangan, Nilai Perusahaan, dan Struktur Kepemilikan terhadap Praktek Perataan Laba: Studi Empiris Perusahaan Manufaktur yang Terdaftar di BEI. Simposium Nasional Akuntansi VIII.

Amanza, A. H., dan Raharjo, S.N. ( 2012). Analisis Faktor-faktor yang Mempengaruhi Praktek Perataan Laba (Income smoothing). Diponegoro Journal of Accounting , Vol.1, No.1, 1-13.

Anggraeni, R. M. (2013). Pengaruh Struktur Kepemilikan Manajerial, Ukuran Perusahaan dan Praktik Corporate Governance Terhadap Manajemen Laba. Diponegoro Journal of Accounting, 2 (3), 113.
Budiasih, Igan. (2009). Faktor-Faktor yang Mempengaruhi Perataan Laba. Jurnal Akuntansi dan Bisnis, Vol.4, No.1.

Dewi, K.S., dan Prasetiono. (2012). Analisis Pengaruh ROA, NPM, DER, dan Size Terhadap Perataan Laba (Studi Empiris Pada Perusahaan Manufaktur Yang Terdaftar Di Bursa Efek Indonesia Periode 2007-2010). Diponegoro Journal of Management. Vol 1, No.4.

Gayatri, Ida Ayu dan Made Gede Wirakusuma. (2013). Faktor-Faktor yang Mempengaruhi Perataan Laba Perusahaan Manufaktur yang Terdaftar Di Bursa Efek Indonesia. E-Jurnal Universitas Udayana.

Ghader, Dadashzadeh dan Zakeri Mohsen. (2014.) The Effect of board Structure and Information Asymmetry on Firm Income Smoothing: Evidence from Listed Companies In Iranian. International Journal of Current Life Sciences. Vol. 4, No. 2, 754-759

Mambraku, Milka Erika dan P. Basuki Hadiprajitno. (2014). Pengaruh Cash Holding dan Struktur Kepemilikan Manajerial Terhadap Income smoothing (Studi Empiris Pada Perusahaan Manufaktur yang terdaftar di Bursa Efek Indonesia Tahun 2010-2012). Diponegoro Journal of Accounting. Vol. 3, No. 2 , 1-9.

Marpaung, Catherine Octorina dan Ni Made Yeni Latrini. (2014). Pengaruh Dewan Komisaris Independen, Komite Audit, Kualitas Audit dan Kepemilikan Manajerial pada Perataan Laba. E-Jurnal Akuntansi Universitas Udayana, Vol.7, No.2, 279-289.

Mitani, Hidetaka. (2010). Additional Evidence on Earnings Managemen and Corporate Governance. Financial Research and Training Center Financial Services Agency Government of Japan. Financial Research and Training Center Discussion Paper Series.

Noviana, Sindi Retno dan Etna Nur Afri Yuyetta. (2011). Analisis Faktor-faktor yang Mempengaruhi Perataan Laba (Studi Empiris Perusahaan Manufaktur yang Terdaftar Di BEI Periode 2006-2010). Jurnal Akuntansi dan Auditing, Vol. 8, No.1, 69-82.

Noviawan, Ridho Alief dan Aditya Septiani. (2013). Pengaruh Mekanisme Corporate Governance Dan Struktur Kepemilikan Terhadap Kinerja 
Keuangan. Diponegoro Journal Of Accounting Vol. 2, No. 3.

Nurmalita, Karina Deavika. (2011). Analisis Pengaruh Karakteristik Perusahaan dan Penerapan Good Corporate governance Terhadap Tindakan Perataan Laba yang Dilakukan oleh Perusahaan Asuransi (Studi Empiris Perusahaan Asuransi Yang Terdaftar di BEI Tahun 2006-2010). Jurnal Universitas Dian Nuswantoro.

Ni Luh Putu Arik Prabayanti dan Gerianta Wirawan Yasa. (2011). Perataan Laba (Income Smoothing) dan Analisis Faktor-Faktor yang Mempengaruhinya (Studi pada Perusahaan Manufaktur yang Terdaftar di Bursa Efek Indonesia). Jurnal Akuntansi dan Bisnis.Vol.1.

Praditia, Okta Rezika. (2010). Analisis Pengaruh Mekanisme Corporate governance Terhadap Manajemen Laba dan Nilai Perusahaan Pada Perusahaan Manufaktur Yang Terdaftar di Bursa Efek Indonesia (BEI) Pada Tahun 20052008. Jurnal Akuntansi dan Auditing, Volume 7, No. 1, 47-63.

Prayudi, Dimas dan Rochmawati Daud. (2013). Pengaruh Profitabilitas, Risiko Keuangan, Nilai Perusahaan dan Struktur Kepemilikan Terhadap Perataan Laba (Income smoothing) Pada Perusahaan Manufaktur Yang Terdaftar Di Bursa Efek Indonesia 20082011. JURNAL JEMASI, Vol. 9, No. 2, 118-134.

Purwanto, Agus. (2009). Kerakteristik Perusahaan, Corporate governance, Keputusan Keuangan, Perataan Laba dan Nilai Perusahaan. Jurnal Maksi, Vol.9, No.2.

Rofika dan Zirman. (2012). Reaksi Pasar Terhadap Tindakan Perataan Laba dengan Mekanisme Good Corporate governance sebagai Variabel Moderasi (Studi Peristiwa Pengumumam Laba Perusahaan. Jurnal Akuntansi, Vol. 1, No. 1, 38-52

Sulistyawati. (2013). Pengaruh Nilai Perusahaan, Kebijakan Dividen, dan Reputasi Auditor
Terhadap Perataan Laba. Accounting Analysis Journal, Vol. 2 , No.2.

Suryani, Indra Dewi dan Raharja. (2010). Pengaruh Mekanisme Corporate governance dan Ukuran Perusahaan Terhadap manajemen Laba Pada Perusahan Manufaktur yang Terdaftar di BEI. E-Journal Undip

Tampubolon, Mayasari. (2012). Pengaruh Leverage. Free Cash Flow, dan Good Corporate governance Terhadap Perataan Laba pada Perusahaan Manufaktur Sektor Industri Dasar Dan Kimia di Bursa Efek Indonesia. Jurnal Akuntansi Fakultas Ekonomi. Universitas Gunadharma.

Utari, Ratih Javariani; Emilia Gustini dan Lukita Tripermat. (2017). Pengaruh Profitabilitas, Financial Leverage, Dan Dividend Payout Ratio Terhadap Perataan Laba Pada Perusahaan Manufaktur Yang Terdaftar Di BEI Tahun 2015. Jurnal Ilmiah Ekonomi Global Masa Kini Vol. 8, No.02.

Widhianningrum, Purweni. (2012). Perataan Laba dan Variabel-Variabel yang Mempengaruhinya (Studi Empiris Perusahaan Manufaktur Yang Terdaftar di BEJ). ASET: Jurnal Akuntansi dan Pendidikan, Vol. 1, No. 1.

Wijaya, Mulyawati. (2009). Analisis Perataan Laba pada Industri Real Estate dan Properti yang Bereputasi Baik di Bursa Efek Indonesia. Jurnal Akuntansi Kontemporer, Vol.1, No.2 : 185-207.

Yulia, Mona. (2013). Pengaruh Ukuran Perusahaan, Profitabilitas, Financial Leverage Dan Nilai Saham Terhadap Perataan Laba (Income Smoothing) Pada Perusahaan Manufaktur Keuangan Dan Pertambangan Yang Terdaftar Di Bursa Efek Indonesia (BEI). Jurnal Akuntansi. Vol 1, No.2. 